\title{
Walidacja procesu spawania jako narzędzie zarządzania jakością
}

\author{
Validation of the welding process \\ as a tool of quality management
}

\begin{abstract}
Streszczenie
W pracy przeanalizowano możliwości zastosowania technologii spawania doczołowych złączy rur w aspekcie uzyskanej jakości połączeń. Wykonano złącza próbne i dokonano szeregu badań nieniszczących i niszczących. Analizę przeprowadzono z punktu widzenia zarządzania procesem i jakością.
\end{abstract}

Słowa kluczowe: walidacja; badania nieniszczące; badania niszczące; zarządzanie jakością

\begin{abstract}
The study investigated the possibility of using the butt welding technology of pipe joints in terms of the obtained quality of connections. Trial couplings were made and a number of non destructive and destructive tests were performed. The analysis was carried out from the perspective of process management and quality.
\end{abstract}

Keywords: validation; non-destructive testing; destructive testing; quality management

\section{Wprowadzenie}

Efektywne i skuteczne zarządzanie procesem wytwarzania determinowane jest czynnikami ludzkimi oraz techniczno-organizacyjnymi. W przypadku procesu wytwarzania opartego na technologiach spawania, czynniki ludzkie to m.in.: właściwe przestrzeganie opracowanej technologii spawania, natomiast techniczno-organizacyjne to np.: szeroko rozumiane warunki spawania, przepływ zasileń i informacji. W pracy została dokonana analiza możliwych do zastosowania technologii spawania doczołowych złączy rur przewodowych instalacji skroplin turbozespołu upustowo-przeciwprężnego 13 UP55, w aspekcie uzyskanej jakości połączeń. Ocena wybranych własności mechanicznych, które determinują jakość złączy, została dokonana na podstawie przeprowadzonych badań nieniszczących i niszczących złączy próbnych.

Spawanie według norm z serii ISO 9000 jest tzw. procesem specjalnym, którego poprawności nie można ocenić wyłącznie po badaniach końcowych. Procesy specjalne wymagają walidacji oraz monitorowania na każdym etapie produkcji. Walidacja przyjętego do wytwarzania procesu spawania jest uznanym standardem $\mathrm{w}$ technice spawalniczej. Zasadniczą częścią tej walidacji jest sprawdzenie technologii spawania w drodze kwalifikacji, w której należy stosować udokumentowane procedury w celu zapewnienia wymaganej jakości złącza spawanego [1,2]. Podstawą do wykonania spawania w warunkach produkcyjnych jest instrukcja technologiczna spawania (Welding Procedure Specification - WPS), która powinna określać wszystkie parametry charakteryzujące proces spawania. Na podstawie przeprowadzanej walidacji może być ona modyfikowana i poprawiana $\mathrm{w}$ zakresie podanych w niej istotnych zmiennych wielkości, które determinują jakość uzyskanego połączenia spawanego. Proces kwalifikowania technologii spawania opisują normy, które nie są jednak obowiązkowe, a stanowią tylko zalecania do stosowania. Celem nadrzędnym kwalifikowania technologii jest udokumentowanie potencjału i jakości (powtarzalności, a więc ograniczenia ilości poprawek spoin) w zakresie danej procedury spawania, potwierdzone zazwyczaj przez niezależną jednostkę. Jakość, oprócz ceny i terminu dostawy, jest najważniejszym kryterium decydującym o wyborze dostawcy. Posiadanie kwalifikowanych technologii jest więc atutem przedsiębiorstwa w ubieganiu się o kontrakty, warunkuje również zdolność do szybszego przystąpienia do wykonywania zlecenia (nie tracąc czasu na kwalifikację). Wykaz kwalifikowanych technologii spawania jest też wartościową referencją, wykorzystywaną przez przedsiębiorstwa do szeroko pojętego marketingu [3 $\div 5]$.

Mgr inż. Mirosława Wiśniewska; dr hab. inż. Maciej Matuszewski - Uniwersytet Technologiczno-Przyrodniczy w Bydgoszczy. Autor korespondencyjny/Corresponding author: matus@utp.edu.pl 


\section{Obiekt badań}

Walidację wybranych technologii spawania przeprowadzono dla złączy próbnych, które zostały wykonane na przykładzie doczołowych złączy rur przewodowych instalacji skroplin turbozespołu upustowo-przeciwprężnego, które z kolei zostały wykonane w ramach remontu i modernizacji turbozespołu upustowo-przeciwprężnego typu 13 UP55W. Rury wykonane były ze stali węglowej S420 o granicy plastyczności $R_{e}=420 \mathrm{MPa}$. Z takiej też stali wykonano złącza próbne do przeprowadzenia badań technologii. Materiał ten należy do grupy 1.3 według CR ISO 15608 [6], czyli są to drobnoziarniste stale normalizowane o $R_{\mathrm{eH}}>360 \mathrm{~N} / \mathrm{mm}^{2}$. Użyty materiał dodatkowy złącza próbnego był również z tej grupy materiałowej.

Do analizy technologii spawania w aspekcie uzyskanej jakości złącza, czyli do kwalifikacji, przyjęto następujące technologie:

- elektrodą otuloną (111), która jest jedną z szeroko stosowanych technologii w warunkach montażowych;

- półautomatyczną w osłonie gazu aktywnego (135), która jest dość uniwersalną oraz wydajną metodą, która coraz częściej wypiera spawanie elektrodami otulonymi.

Do kwalifikacji technologii spawania złączy doczołowych rur wybrano metodę kwalifikacji przez badania technologii spawania według PN-EN ISO 15614-1 [7]. Polega ona na kwalifikowaniu WPS na podstawie wykonania według niej znormalizowanego złącza spawanego i zbadania go w zakresie zgodnym z normą. Ogólny algorytm kwalifikacji przedstawiono na rysunku 1.

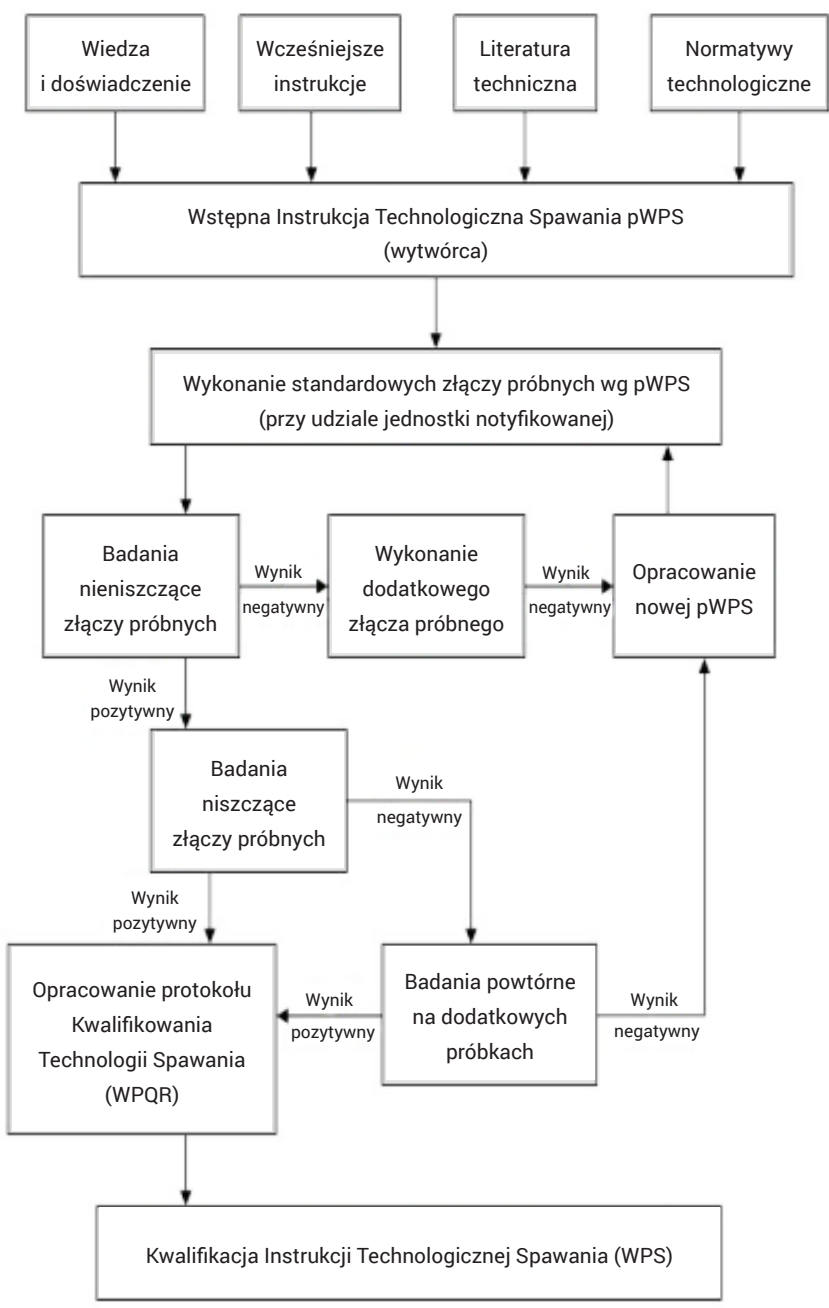

Rys. 1. Algorytm kwalifikowania technologii spawania poprzez badanie [8]

Fig. 1. Algorithm for qualification of welding technology through testing
Dla zbadania technologii spawania w celu jej kwalifikacji zgodnie z PN-EN ISO 15614-1 [7], należy wykonać złącze o wymiarach wskazanych w tej normie (rys. 2).

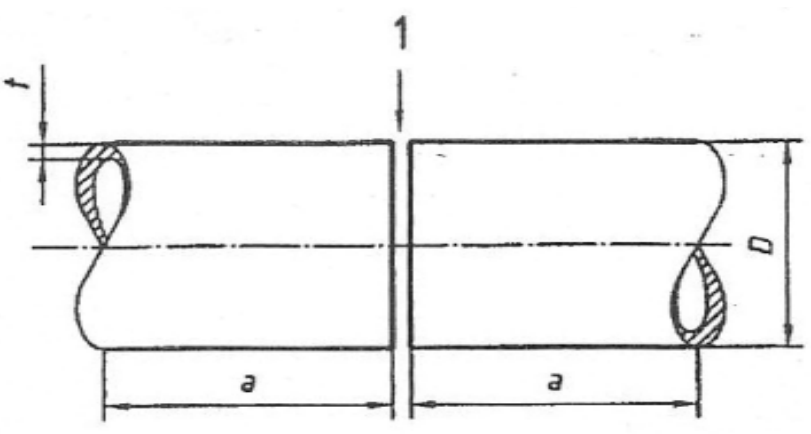

Rys. 2. Złącze próbne dla złącza doczołowego rury z pełnym przetopem (opis w tekście) [7]

Fig. 2. Test connector for butt plug full-pipe (description in the text)

Przygotowanie - dopasowanie i wykonanie złącza (1), należy wykonać zgodnie z opracowaną wstępną instrukcją technologiczną spawania (pWPS), uwzględniając średnicę zewnętrzną rury $(D=193,7 \mathrm{~mm}$ ) oraz grubość łączonego materiału $(\mathrm{t}=11 \mathrm{~mm})$. Minimalna długość rury użytej do wykonania złącza to $150 \mathrm{~mm}$ (a).

Złącze próbne przygotowano z ukosowaniem symetrycznym na V. Natomiast do wykonania złącza, dla obydwóch badanych technologii, przyjęto 5 ściegów. Spawanie elektrodą otuloną przebiegało przy następujących parametrach:

- wymiar spoiwa: dla pierwszego ściegu 2,4 mm,

dla pozostałych $3,0 \mathrm{~mm}$;

- natężenie prądu: $95 \div 125[\mathrm{~A}]$;

- napięcie łuku: $12 \div 14$ [V].

Natomiast dla półautomatycznego spawania w osłonie gazu aktywnego przyjęto następujące parametry:

- wymiar spoiwa: dla pierwszego ściegu 1,0 mm, dla pozostałych 1,2 $\mathrm{mm}$;

- natężenie prądu: $105 \div 135[\mathrm{~A}]$;

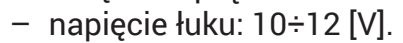

$\mathrm{Na}$ rysunku 3 zilustrowano wygląd złączy poszczególnych metod po spawaniu.
Widok
od strony lica
Widok od strony grani

a)

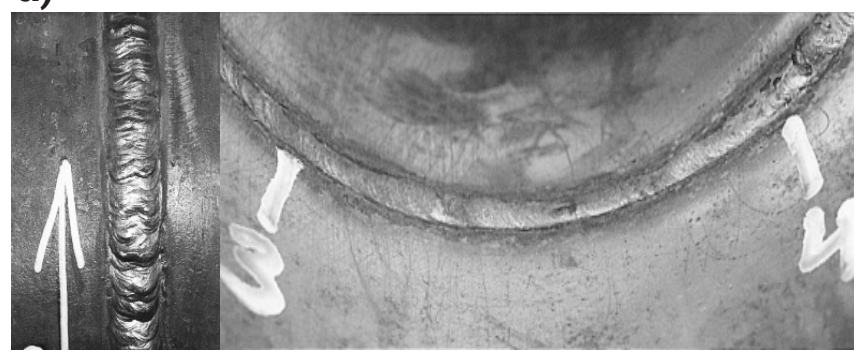

b)

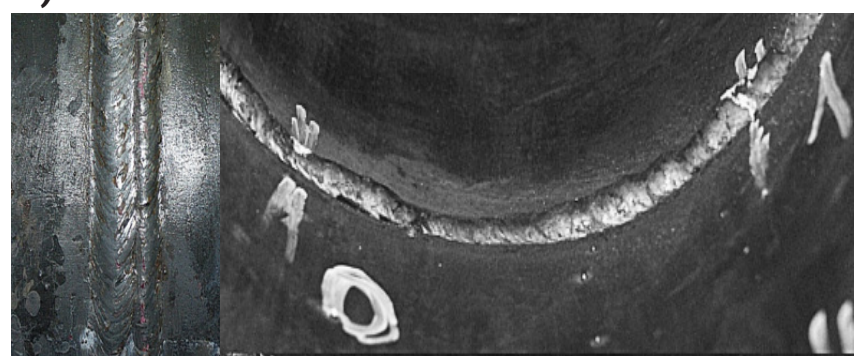

Rys. 3. Wygląd złącza próbnego: a) metoda 111, b) metoda 135 Fig. 3. Appearance of the test connector. a) method 111, b) method 135 
Do badań złącza próbnego przyjęto zarówno badania nieniszczące (tzw. badania NDT), jak i niszczące. Zakres ten zależy m.in. od:

- kształtu złącza próbnego (złącze doczołowe blach, złącze doczołowe rur, złącze teowe, złącze odgałęzione); - grubości i gatunku materiału.

Dla założonego do kwalifikacji technologii złącza próbnego (złącze doczołowe rur o grubości $11 \mathrm{~mm} \mathrm{z}$ materiału w gatunku S420) w tablicy I zestawiono typy i szczegółowe zakresy badań.

Miejsce pobrania próbek do poszczególnych badań niszczących wskazane jest w normie [7] jak i publikacjach niezależnych jednostek kwalifikujących technologie [9]. Wymagane próbki powinny być pobrane po zakończeniu badań nieniszczących i spełnieniu ich kryteriów.

Tablica I. Zakres badań złącza próbnego do kwalifikacji technologii spawania [7]

Table I. Test specimen scope for qualification of welding technology

\begin{tabular}{|c|c|c|}
\hline & Typ badania & Zakres badania \\
\hline \multirow{3}{*}{ 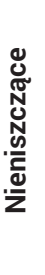 } & Wizualne VT & $100 \%$ \\
\hline & $\begin{array}{c}\text { Radiograficzne RT } \\
\text { (lub ultradźwiękowe UT) }\end{array}$ & $100 \%$ \\
\hline & $\begin{array}{l}\text { Penetracyjne PT } \\
\text { (lub magnetyczno- } \\
\text { proszkowe MT) }\end{array}$ & $100 \%$ \\
\hline \multirow{5}{*}{ 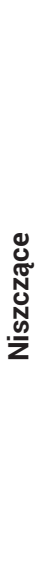 } & $\begin{array}{l}\text { Badanie na rozciąganie } \\
\text { poprzeczne }\end{array}$ & 2 próbki \\
\hline & $\begin{array}{l}\text { Badanie na zginanie } \\
\text { poprzeczne }\end{array}$ & $\begin{array}{c}4 \text { próbki } \\
\text { (2 z rozciąganiem lica } \\
\text { i } 2 \text { z rozciąganiem grani) }\end{array}$ \\
\hline & Badanie udarności & $\begin{array}{c}2 \text { zestawy } \\
\text { (oś spoiny i linia wtopienia) }\end{array}$ \\
\hline & Badanie twardości & $\begin{array}{l}2 \text { linie } \\
\text { (po } 3 \text { odciski w spoinie, obu } \\
\text { strefach wpływu ciepła i obu } \\
\text { materiałach podstawowych) }\end{array}$ \\
\hline & Badanie makroskopowe & 1 zgład \\
\hline
\end{tabular}

\section{Analiza wyników badań złączy próbnych}

Dla badań nieniszczących wynikiem badań jest poziom jakości według normy

PN-EN ISO 5817 [10]. Poziom jakości charakteryzuje jakość złącza spawanego w oparciu o rodzaj i wielkość niezgodności spawalniczych (skatalogowanych w normie PN-EN ISO 6520-1 [11]) i jest ustalany w oparciu o wymiar graniczny dla danej niezgodności.

Wyniki badań wizualnych, radiograficznych oraz penetracyjnych dla badanych metod spawania spełniały poziom jakości B wg EN ISO 5817 [10].

Badanie na rozciąganie poprzeczne przeprowadzono zgodnie z PN-EN 895 [12] w temperaturze $20^{\circ} \mathrm{C}$ na urządzeniu ZD-40 o zakresie siły rozciągającej $8 \div 400 \mathrm{kN}$ i działce elementarnej 2,0 kN. Wyniki próby rozciągania - siłę zrywającą dla każdej z dwóch próbek oraz wytrzymałość na rozciąganie (siłę odniesioną do przekroju poprzecznego zrywanej próbki) zawiera tablica II.

Na rysunku 4 przedstawiono próbki po badaniu na rozciąganie poprzeczne.
Tablica II. Wyniki badania na rozciąganie poprzeczne Table II. Transverse tensile test results

\begin{tabular}{|c|c|c|c|c|}
\hline \multicolumn{4}{|c|}{ Rozciąganie } & \multirow[b]{2}{*}{ Uwagi: } \\
\hline $\begin{array}{c}\text { Metoda } \\
\text { spawa- } \\
\text { nia }\end{array}$ & $\begin{array}{c}\text { Wymiary } \\
\text { próbki } \\
\text { [mm] }\end{array}$ & $\begin{array}{c}\text { Siła } \\
\text { zrywająca } \\
\text { F }_{\mathrm{m}}[\mathbf{k N}]\end{array}$ & $\begin{array}{c}\text { Wytrzy- } \\
\text { małość } \\
\text { na rozcią- } \\
\text { ganie } \\
\mathrm{R}_{\mathrm{m}} \text { [MPa] }\end{array}$ & \\
\hline \multirow{2}{*}{111} & $24,20 \times 11,40$ & 150,0 & 543,71 & $\begin{array}{c}\text { zerwanie } \\
\text { poza spoiną }\end{array}$ \\
\hline & $24,30 \times 11,60$ & 150,0 & 532,14 & $\begin{array}{c}\text { zerwanie } \\
\text { poza spoiną }\end{array}$ \\
\hline \multirow[b]{2}{*}{135} & $24,90 \times 11,30$ & 150,0 & 533,11 & $\begin{array}{c}\text { zerwanie } \\
\text { poza spoiną }\end{array}$ \\
\hline & $24,80 \times 11,70$ & 157,0 & 541,08 & $\begin{array}{c}\text { zerwanie } \\
\text { poza spoiną }\end{array}$ \\
\hline
\end{tabular}
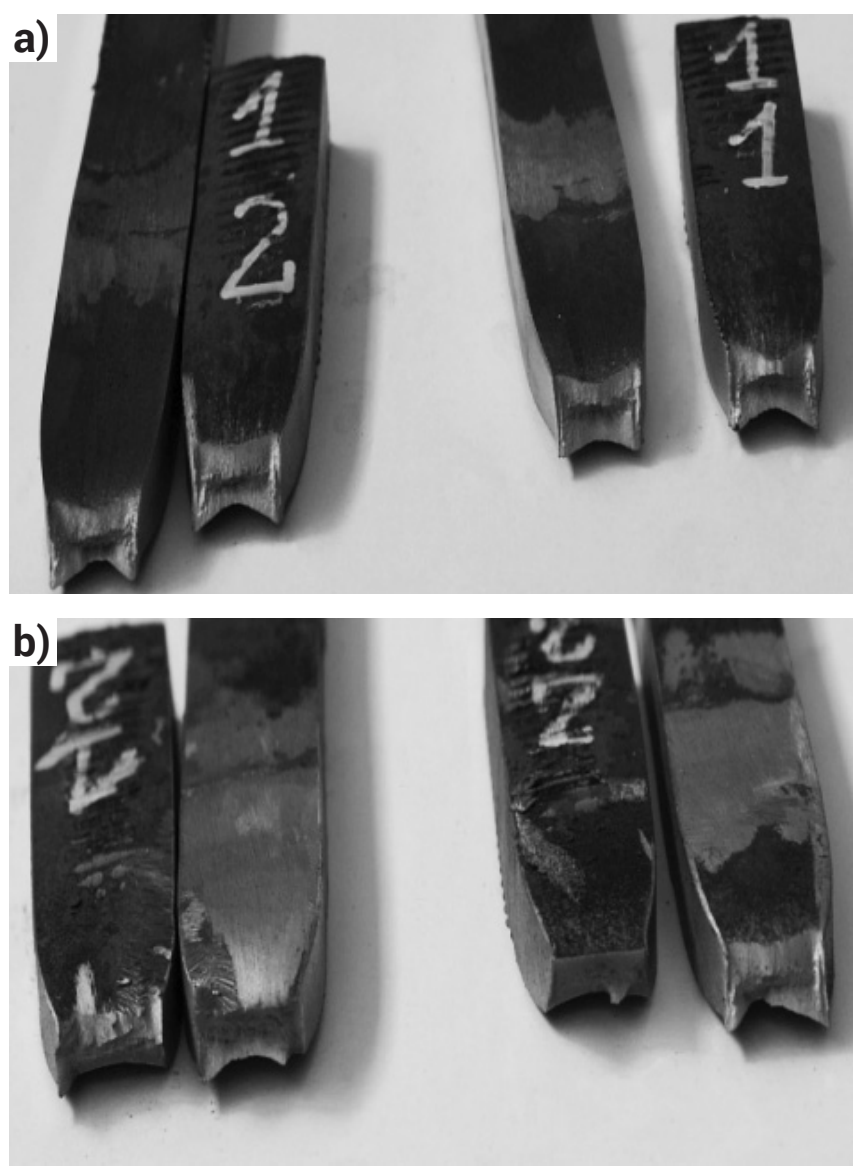

Rys. 4. Wygląd złącza próbnego po badaniu na rozciąganie: a) metoda 111, b) metoda 135

Fig. 4. Appearance of the test connector after the tensile test: a) method 111, b) method 135

Badanie na zginanie poprzeczne przeprowadzono zgodnie z PN-EN ISO 6892-1 [13] w temperaturze $20^{\circ} \mathrm{C}$, podobnie jak badanie na rozciąganie, na maszynie wytrzymałościowej ZD-40 o zakresie siły rozciągającej $8 \div 400 \mathrm{kN}$ i działce elementarnej 2,0 kN. Zastosowano trzpień o średnicy czterech grubości blachy. Próbę przeprowadzono na 2 próbkach FBB1 (rozciąganie strony lica) i 2 FBB2 (rozciąganie strony grani). Wyniki przedstawiono w tablicy III.

Próbki po badaniu na zginanie poprzeczne przedstawiono na rysunku 5. 


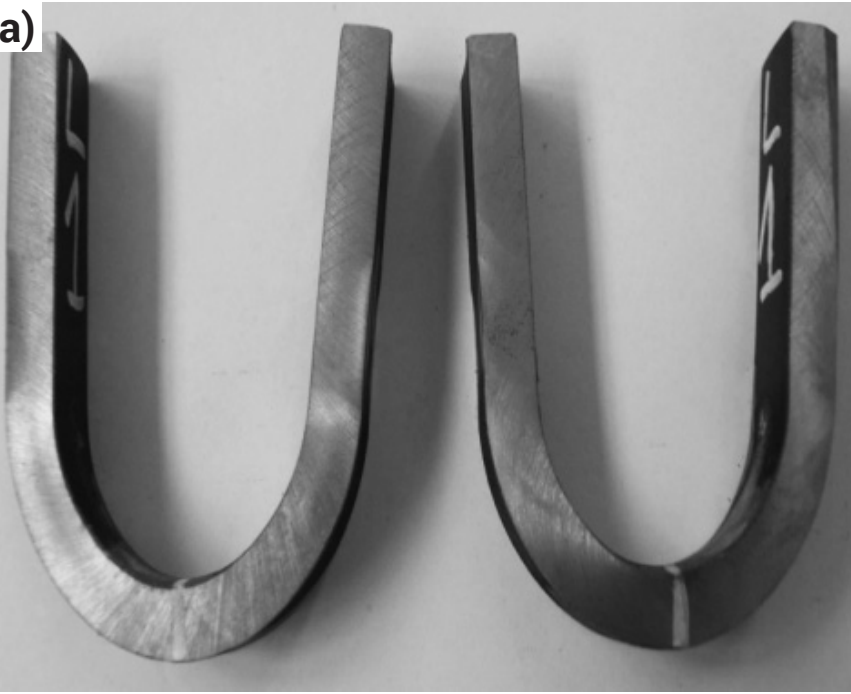

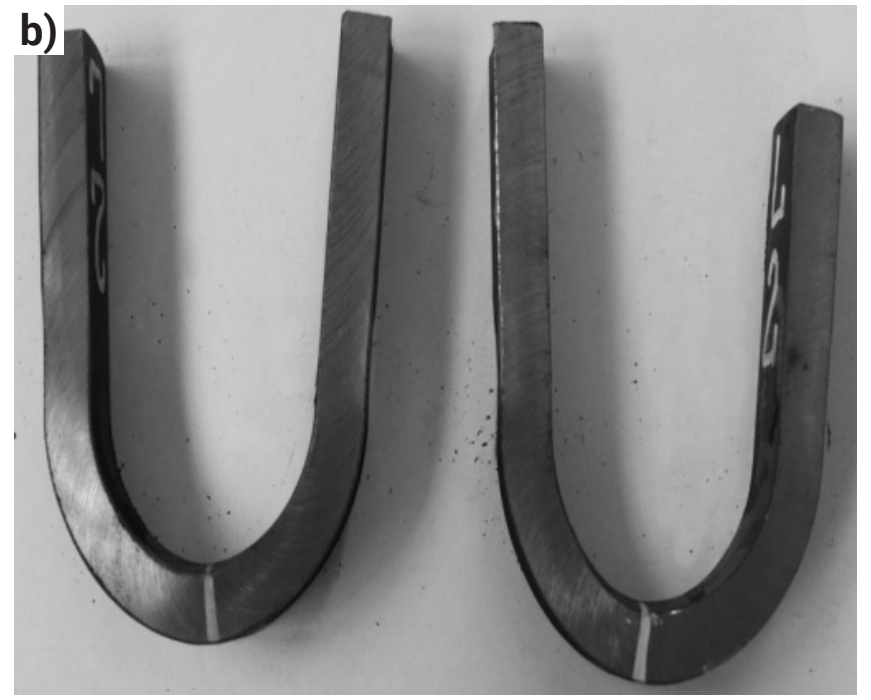

Rys. 5. Wygląd złącza próbnego po badaniu na zginanie: a) metoda 111, metoda 135

Fig. 5. Appearance of the test connector after the bending test a) method 111, b) method 135

Tablica III. Wyniki badania na zginanie poprzeczne Table III. Transverse bend test results

\begin{tabular}{|c|c|c|c|c|}
\hline \multicolumn{4}{|c|}{ Zginanie } & \multirow{2}{*}{ Uwagi } \\
\hline $\begin{array}{c}\text { Metoda } \\
\text { spawa- } \\
\text { nia }\end{array}$ & $\begin{array}{c}\text { Wymiary } \\
\text { próbki } \\
{[\mathrm{mm}]}\end{array}$ & $\begin{array}{c}\text { Średnica } \\
\text { trzienia } \\
\mathbf{k} \mathrm{g} / \mathrm{t} /\end{array}$ & $\begin{array}{c}\text { Kąt } \\
\text { gięcia } \\
{\left[{ }^{\circ}\right]}\end{array}$ & \\
\hline \multirow{4}{*}{111} & $20,0 \times 11,0$ & $4 \cdot \mathrm{t}$ & 180 & FBB1 bez uwag \\
\cline { 2 - 5 } & $20,0 \times 11,0$ & $4 \cdot \mathrm{t}$ & 180 & FBB1 bez uwag \\
\cline { 2 - 5 } & $20,0 \times 11,0$ & $4 \cdot \mathrm{t}$ & 180 & FBB2 bez uwag \\
\cline { 2 - 5 } & $20,0 \times 11,0$ & $4 \cdot \mathrm{t}$ & 180 & FBB2 bez uwag \\
\hline \multirow{4}{*}{135} & $20,0 \times 11,0$ & $4 \cdot \mathrm{t}$ & 180 & FBB1 bez uwag \\
\cline { 2 - 5 } & $20,0 \times 11,0$ & $4 \cdot \mathrm{t}$ & 180 & FBB1 bez uwag \\
\cline { 2 - 5 } & $20,0 \times 11,0$ & $4 \cdot \mathrm{t}$ & 180 & FBB2 bez uwag \\
\cline { 2 - 5 } & $20,0 \times 11,0$ & $4 \cdot \mathrm{t}$ & 180 & FBB2 bez uwag \\
\hline
\end{tabular}

Badanie udarności przeprowadzono zgodnie z PN-EN ISO 9016 [14] w temperaturze $-40^{\circ} \mathrm{C}$ na młocie Charpy'ego PSW-30 o zakresie energii $0 \div 300 \mathrm{~J}$ i działce elementarnej $1,0 \mathrm{~J}$. Badanie przeprowadzono dla zestawu 3 próbek z karbem $\mathrm{V}$ usytuowanym prostopadle do powierzchni złącza z osi spoiny (VWT 0/2) oraz zestawu 3 próbek z karbem $\mathrm{V}$ usytuowanym prostopadle do powierzchni złącza z linii wtopienia (VHT 0/2) dla każdej metody spawania. Wyniki - energię łamania dla każdej z próbek z każdego zestawu oraz wartości średnie zawarto w tablicy IV.

Na rysunku 6 przedstawiono próbki po badaniu udarności.

Badanie twardości przeprowadzono zgodnie z PN-EN ISO 6507-1 [15] na urządzeniu HPO-250 z obciążeniem $98 \mathrm{~N}$ oznaczając twardość HV10. Dla metody spawania 111 twardość spoiny oraz strefy wpływu ciepła zawierała się w przedziale $187 \div 221 \mathrm{HV}$. Natomiast dla metody 135 , twardość ta zawierała się między 170 a $206 \mathrm{HV}$.

Badanie makroskopowe wykonano na zgładzie metalograficznym przekroju poprzecznego złącza. Po szlifowaniu zgład, w celu ujawnienia niezgodności, struktury i budowy spoiny oraz wielkości strefy wpływu ciepła, został wytrawiony odczynnikiem Adlera. Wyniki badań makroskopowych dla badanych metod spawania spełniały poziom jakości B wg EN ISO 5817 [10].
Tablica IV. Wyniki badania udarności Table IV. Impact strength test results

\begin{tabular}{|c|c|c|c|}
\hline \multicolumn{3}{|c|}{ Udarność } & \multirow[b]{2}{*}{ Uwagi } \\
\hline $\begin{array}{c}\text { Metoda } \\
\text { spawa- } \\
\text { nia }\end{array}$ & $\begin{array}{c}\text { Wymiary } \\
\text { próbek } \\
\text { [mm] }\end{array}$ & $\begin{array}{c}\text { Energia } \\
\text { łamania } \\
\text { [J] }\end{array}$ & \\
\hline \multirow{8}{*}{111} & $7,5 \times 10,0$ & 45 & (WELD) VWT 0/2 \\
\hline & $7,5 \times 10,0$ & 48 & (WELD) VWT 0/2 \\
\hline & $7,5 \times 10,0$ & 43 & (WELD) VWT 0/2 \\
\hline & Średnia & 45,3 & \\
\hline & $7,5 \times 10,0$ & 49 & (F.L.) VHT 0/2 \\
\hline & $7,5 \times 10,0$ & 46 & (F.L.) VHT 0/2 \\
\hline & $7,5 \times 10,0$ & 51 & (F.L.) VHT 0/2 \\
\hline & Średnia & 48,6 & \\
\hline \multirow{8}{*}{135} & $7,5 \times 10,0$ & 49 & (WELD) VWT 0/2 \\
\hline & $7,5 \times 10,0$ & 47 & (WELD) VWT 0/2 \\
\hline & $7,5 \times 10,0$ & 41 & (WELD) VWT 0/2 \\
\hline & Średnia & 45,6 & \\
\hline & $7,5 \times 10,0$ & 48 & (F.L.) VHT 0/2 \\
\hline & $7,5 \times 10,0$ & 56 & (F.L.) VHT 0/2 \\
\hline & $7,5 \times 10,0$ & 52 & (F.L.) VHT 0/2 \\
\hline & Średnia & 52 & \\
\hline
\end{tabular}

W celu oceny poprawności połączeń, a tym samym opracowanej technologii spawania, zestawiono wyniki (tabl. V i VI) wszystkich wykonanych badań z kryterium wskazanym w PN-EN ISO 15614-1 [7].

Z przedstawionego zestawienia wynika, że są spełnione wymagane kryteriów wyników wszystkich badań nieniszczących i niszczących złącza próbnego każda z analizowanych metod spawania została zakwalifikowana, jako dająca pożądaną jakość złącza doczołowego spawanych rur. 

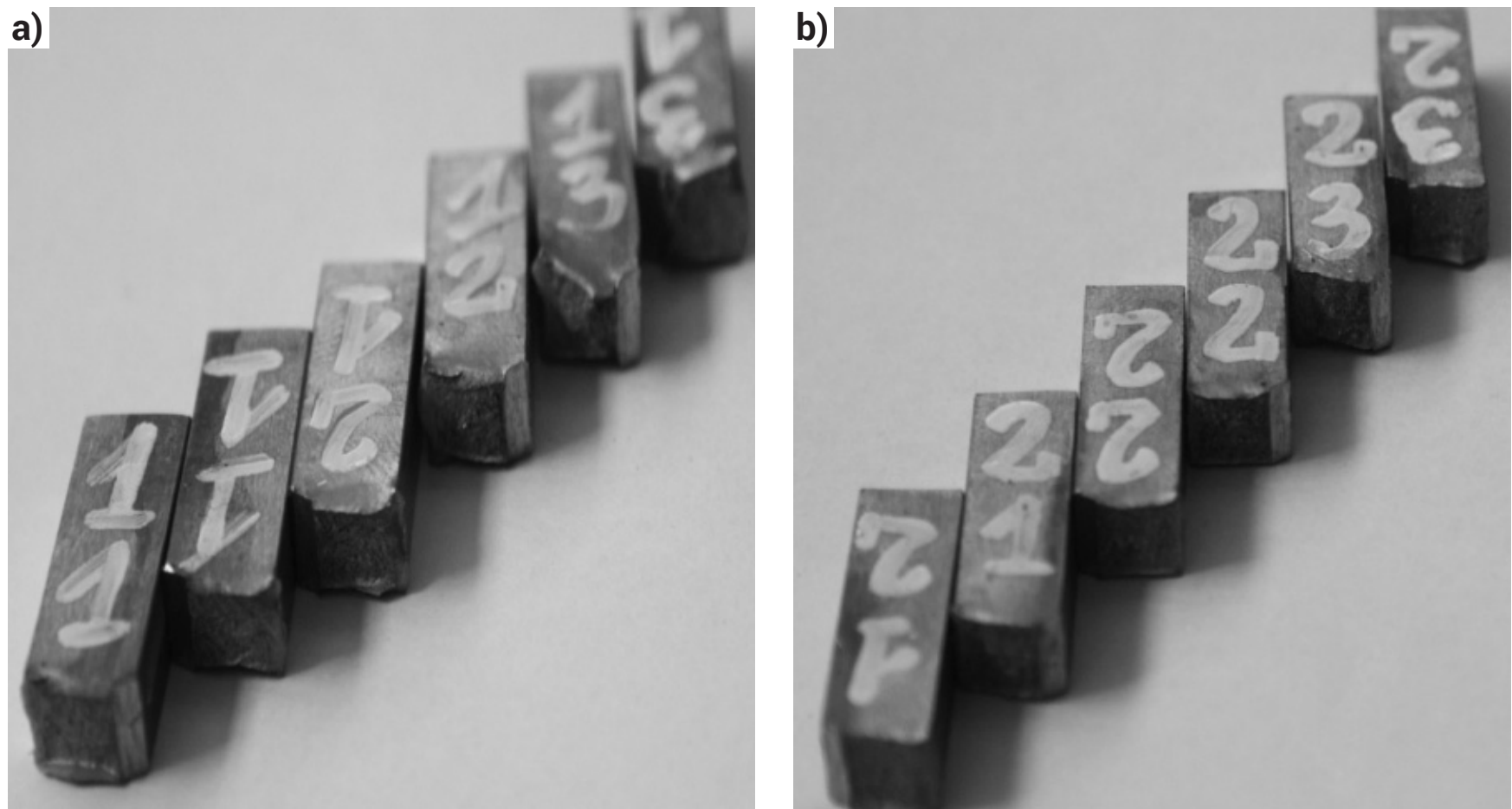

Rys. 6. Wygląd złącza próbnego po badaniu udarności: a) metoda 111, metoda 135

Fig. 6. Appearance of the test connector after the impact strength test a) method 111, b) method 135

Tablica V. Wyniki badań nieniszczących złącza próbnego do kwalifikacji technologii spawania i kryteria akceptacji wg PN-EN ISO 15614-1 [7] Table V. Non-destructive test connector test results for welding qualification and acceptance criteria acc. PN-EN ISO 15614-1 [7]

\begin{tabular}{|c|c|c|c|}
\hline Badanie & Metoda spawania & Wynik & Kryterium akceptacji wg EN ISO 15614-1 \\
\hline \multirow{2}{*}{ Wizualne VT } & 111 & Poziom jakości B wg PN-EN ISO 5817 & \multirow{2}{*}{ Poziom jakości B wg PN-EN ISO 5817} \\
\hline & 135 & Poziom jakości B wg PN-EN ISO 5817 & \\
\hline \multirow{2}{*}{ Radiograficzne RT } & 111 & Poziom akceptacji 1 wg PN-EN ISO 5817 & \multirow[t]{2}{*}{ Poziom akceptacji 1 wg PN-EN ISO 5817} \\
\hline & 135 & Poziom akceptacji 1 wg PN-EN ISO 5817 & \\
\hline \multirow{2}{*}{ Penetracyjne PT } & 111 & $\begin{array}{l}\text { Poziom akceptacji } 1 \text { wg PN-EN ISO } 5817 \\
\text { Poziom akceptacji 2x wg EN ISO } 23278\end{array}$ & \multirow{2}{*}{ Poziom akceptacji 1 wg PN-EN ISO 5817} \\
\hline & 135 & $\begin{array}{l}\text { Poziom akceptacji } 1 \text { wg PN-EN ISO } 5817 \\
\text { Poziom akceptacji 2x wg EN ISO } 23278\end{array}$ & \\
\hline
\end{tabular}

Tablica VI. Wyniki badań niszczących złącza próbnego do kwalifikacji technologii spawania i kryteria akceptacji wg PN-EN ISO 15614-1 [7] Table VI. Destructive test connector test results for welding qualification and acceptance criteria acc. PN-EN ISO 15614-1 [7]

\begin{tabular}{|c|c|c|c|}
\hline Badanie & $\begin{array}{l}\text { Metoda } \\
\text { spawania }\end{array}$ & Wynik & Kryterium akceptacji wg EN ISO 15614-1 \\
\hline \multirow{2}{*}{$\begin{array}{l}\text { Badanie na rozciąganie } \\
\text { poprzeczne }\end{array}$} & 111 & $\begin{array}{l}\mathrm{R}_{\mathrm{m}}=543,71 \mathrm{MPa} \\
\mathrm{R}_{\mathrm{m}}=532,14 \mathrm{MPa}\end{array}$ & \multirow{2}{*}{$\begin{array}{c}R_{m} \text { nie niższe niż } R_{m} \text { dla materiału } \\
\text { podstawowego } \\
\left(S 420-R_{m} \text { min. }=470 M P a \text { wg EN 10025) }\right.\end{array}$} \\
\hline & 135 & $\begin{array}{l}\mathrm{R}_{\mathrm{m}}=533,11 \mathrm{MPa} \\
\mathrm{R}_{\mathrm{m}}=541,08 \mathrm{MPa}\end{array}$ & \\
\hline \multirow{2}{*}{$\begin{array}{l}\text { Badanie na zginanie } \\
\text { poprzeczne }\end{array}$} & 111 & $\begin{array}{c}\text { Kąt gięcia } 180^{\circ} \\
\text { Brak pęknięć i naderwań > 3,0 mm }\end{array}$ & \multirow{2}{*}{$\begin{array}{c}\text { Kąt gięcia } 180^{\circ}, \\
\text { Brak pęknięć i naderwań > 3,0 mm }\end{array}$} \\
\hline & 135 & $\begin{array}{c}\text { Kąt gięcia } 180^{\circ} \\
\text { Brak pęknięć i naderwań > 3,0 mm }\end{array}$ & \\
\hline \multirow{2}{*}{ Badanie udarności } & 111 & $\begin{array}{l}\mathrm{KV}_{-40^{\circ} \mathrm{C}} \mathrm{VWT} 0 / 2=45,3 \mathrm{~J} \\
\mathrm{KV}_{-40^{\circ} \mathrm{C}} \mathrm{VHT} 0 / 2=48,6 \mathrm{~J}\end{array}$ & \multirow{2}{*}{$\mathrm{KV} \mathrm{w}-40^{\circ} \mathrm{C}$ minimalnie $27 \mathrm{~J}$ dla $\mathrm{S} 420$} \\
\hline & 135 & $\begin{array}{c}\mathrm{KV}_{-40^{\circ} \mathrm{C}} \mathrm{VWT} 0 / 2=45,6 \mathrm{~J} \\
\mathrm{KV}_{-40^{\circ} \mathrm{C}} \mathrm{VHT} 0 / 2=52 \mathrm{~J}\end{array}$ & \\
\hline \multirow{2}{*}{ Badanie twardości } & 111 & $H V 10=187 \div 221$ & \multirow{2}{*}{ Maksymalnie 380 HV10 } \\
\hline & 135 & $\mathrm{HV} 10=170 \div 206$ & \\
\hline \multirow{2}{*}{ Badanie makroskopowe } & 111 & Poziom jakości B wg PN-EN ISO 5817 & \multirow{2}{*}{ Poziom jakości B wg PN-EN ISO 5817} \\
\hline & 135 & Poziom jakości B wg PN-EN ISO 5817 & \\
\hline
\end{tabular}




\section{Podsumowanie i wnioski}

Próbne złącza doczołowe rur wykonane każdą z metod spawania przedstawionych w pracy posiadało wyniki zadowalające w porównaniu do stawianych im kryterium akceptacji. Wyniki badań nieniszczących we wszystkich metodach dały pożądaną jakość złącza doczołowego. Natomiast wyniki badań niszczących każdej z metody spełniały kryterium z pewną rezerwą, pozwalającą na pozytywną ocenę własności mechanicznych złączy.

W rozpatrywanym przypadku doboru technologii spawania doczołowych złączy rur przewodowych instalacji skroplin turbozespołu upustowo-przeciwprężnego 13 UP55, w aspekcie uzyskanej jakości połączeń, obydwie analizowane technologie mogą zostać zastosowane. Pozytywny wynik technologii pozwala na wystąpienie certyfikacji procesu spawania do niezależnych jednostek poprzez wydanie protokołu kwalifikacji technologii spawania (WPQR). Posiadanie takiej kwalifikacji technologii spawania z punktu widzenia zarządzania jakością jest pożądane. W rozpatrywanym przypadku znacznie skróciłoby proces wytwórczy, bez obaw niespełnienia wymagań związanych ze szczelnością i wytrzymałością.

Jednak w celu wyboru najkorzystniejszej metody spawania powinno się przyjmować nie tylko kryteria techniczne, ale również ekonomiczne. Poprawne określenie tych kryteriów pozwala przygotować produkcję, która umożliwia zapewnienie wymaganej jakości połączeń spawanych oraz wysokiej wydajności, przy kryteriach ekonomicznych. Konieczność opracowania tych warunków wynika z wymagań systemu zarządzania i sterowania jakością.

\section{Literatura}

[1] Kuzio T.: Kwalifikowanie technologii spawalniczych przez Instytut Spawalnictwa, Biuletyn Instytutu Spawalnictwa Nr 2/2007, s. 50-54.

[2] Saperski M.: Procedura kwalifikowania technologii spawania konstrukcji offshore wg przepisów DNV, Biuletyn Instytutu Spawalnictwa Nr 6/2010 s. $57-62$.

[3] Warsz K., Czwórnóg B.: Wpływ badania i uznawania technologii spawania na jakość i koszty produkcji, Biuletyn Instytutu Spawalnictwa Nr 5/2000 s. $36-43$.

[4] Słania J.: Plan spawania carg płaszcza obrotowego, Przegląd Spawalnictwa $2 / 2011$ s. $36-40$.

[5] Słania J.: Istota planu spawania, Przegląd Spawalnictwa $2 / 2011$ s. 3-9.

[6] Norma PN-CR ISO 15608:2002 Spawanie - Wytyczne systemu podziału materiałów metalowych na grupy.

[7] Norma PN-EN ISO 15614-1:2008 Specyfikacja i kwalifikowanie technologii spawania metali - Badanie technologii spawania - Część 1: Spawanie łukowe i gazowe stali oraz spawanie łukowe niklu i stopów niklu.
[8] http://www.e-spawalnik.pl.

[9] Zasady kwalifikowania technologii spawania Wytyczne 74/P, PRS, 2007r.

[10] Norma PN-EN ISO 5817:2009 Spawanie - Złącza spawane ze stali, niklu, tytanu i ich stopów (z wyjątkiem spawanych wiązką). Poziomy jakości według niezgodności spawalniczych

[11] PN-EN ISO 6520-1:2009 Spawanie i procesy pokrewne - Klasyfikacja geometrycznych niezgodności spawalniczych w metalach - Część 1: Spawanie.

[12] PN-EN 895:1997 Badania niszczące spawanych złączy metali - Próba rozciągania próbek poprzecznych.

[13] PN-EN ISO 6892-1:2010 Metale - Próba rozciągania - Część 1: Metoda badania w temperaturze pokojowej.

[14] PN-EN ISO 9016:2011 Badania niszczące złączy spawanych metali - Badanie udarności - Usytuowanie próbek, kierunek karbu i badanie.

[15] PN-EN ISO 6507-1:2007 Metale - Pomiar twardości sposobem Vickersa - Część 1: Metoda badań. 